Jurnal Saintek Perikanan Vol. 6, No. 2, 2011, 84 - 90

\title{
A REVIEW OF PEARL OYSTER (Pinctada maxima) CULTUREIN GENERAL
}

\author{
Ludi Parwadani Aji \\ Technical Implementation Unit For Marine Biology Conservation, Research Centre For Oceanography, \\ Indonesian Institute Of Science (LIPI), Biak - Papua Barat, \\ e-mail : ludi_bio@yahoo.co.id
}

Diserahkan : 19 Januari 2011; Diterima : 10 Februari 2011

\begin{abstract}
Pearl oyster culture is unique because the product is gem not flesh and one of the species that produce pearl is Pinctada maxima (Silver or Gold lip pearl oyster). Stock for pearl oyster production can be collected from the wild or hatchery. However, hatchery production is a better solution to supply P.maxima for pearl production rather than just depend on wild stocks. Spat from the wild or hatchery will be grown-out for pearl production by longline or raft culture system method in ocean. Raft culture provide a work platform to repair, clean and store culture tools, while, longline culture has better design to deal with wave or wind exposure. There are identified different culture systems according different species (for example between P.maxima and P.fucata) and locations. Several constraints on P. maxima culture also identify such as biofouling organisms, predations and diseases that can reduce productivity and pearl quality. For example, mass mortalities of P.maxima occurred in Western Australia due to viral infection and it disrupted the pearl oyster industry. Therefore, several strategies are needed to mitigate those problems to achieve maximal productivity by using good management culture practice.
\end{abstract}

Key word: pearl oyster, P. maxima, management, culture

\section{INTRODUCTION}

Pinctada maxima is the largest species of the genus Pinctada and called the "Silver or Gold lip pearl oyster" due to the white color of the valve edge and silver/gold color from the pearl that they have produced (Gervis and Sims 1992). Individuals of Pinctada maxima live in rocky, gravel or sandy bottoms and reef environments (Hwang and Okutani 2003). Furthermore, it is found principally in the central Indo-Pacific region including part of The South China Sea, southern Japan, southeast Asia, Australia, Papua New Guinea and Polynesia (Gervis and Sims 1992, Hwang and Okutani 2003). Pinctada maxima is commonly cultured in northern Australia and south east Asia, being the largest marine pearl producing species which supplies almost half of the total pearl production around the world (Southgate and Lucas 2008).

Therefore, this article reviews the literature on the culture systems method (longline and raft culture) and management practices to culture Pinctada maxima. It will also identify the management obstacles such as disease, predation and biofouling on Pinctada maxima culture and the strategies to solve these problems.

\section{Source of Culture Stock}

Pearl oyster farms need to have a regular stock of oyster individuals to maintain pearl production. Many industries of pearl oyster farming rely on the collection of adult pearl oysters from the wild. For example, the pearl industry in north-western Australia has taken adult P.maxima $(120-170 \mathrm{~mm})$ from the wild by divers (Wells and Jernakoff 2006). Adult pearl oysters large enough receive a nucleus from which a pearl develops, while, the small ones will be grown until they are ready for nucleus insertion (Southgate and Lucas 2008).

Many methods to collect spat from the wild that applied in hatchery reared P.maxima. Spat collectors are made up of various materials such as oyster shells, plastic, frayed rope, tree branches and pieces of coral and hang from floating structures like rafts or longlines (Gervis and Sims 1992). Therefore, spat will attach to those materials allowing farmers to collect them and use them as seed stock. Besides the materials 
which compose the spat collectors, several factors such as season, depth and location also influence the success of spat collection (Friedman et al. 1998).

However, hatchery production is a good solution to supply P.maxima for pearl production rather than just depend on wild stocks (Vakily 1989). Nowadays, Pearl oyster aquaculture industries collect their larvae or spat from hatchery production reducing the need to collect them from the wild. This eliminates the potential problem that uncontrollable environmental conditions (salinity, food availability, temperature, etc) in the wild provide unreliable stock (Borowitzka 1997). In hatchery production, firstly, the broodstock shell must be cleaned to reduce bacterial contamination and placed in a shallow communal spawning tank. Increasing temperature from $3^{\circ}-5^{\circ} \mathrm{C}$ above ambient reaching a maximum of $33^{\circ}-34^{\circ} \mathrm{C}$ is necessary to induce spawning (Rose 1990). This induces the male P.maxima to spawn and the presence of sperm stimulates female to release eggs (Alagarswami et al. 1983). After that, fertilized eggs are incubated in filtered and aerated seawater tanks with egg density not more than 30 per $\mathrm{mL}$ for around one day to allow larval development through to the veliger stage (larva with the shell) (Rose 1990). Then, larvae are drained from the incubation tanks which water drains from the tank through an appropriately sized sieve mesh which retains the larvae (Figure 1). Furthermore, larvae are resuspended into clean sea water, counted and transferred to clean larval culture tanks.

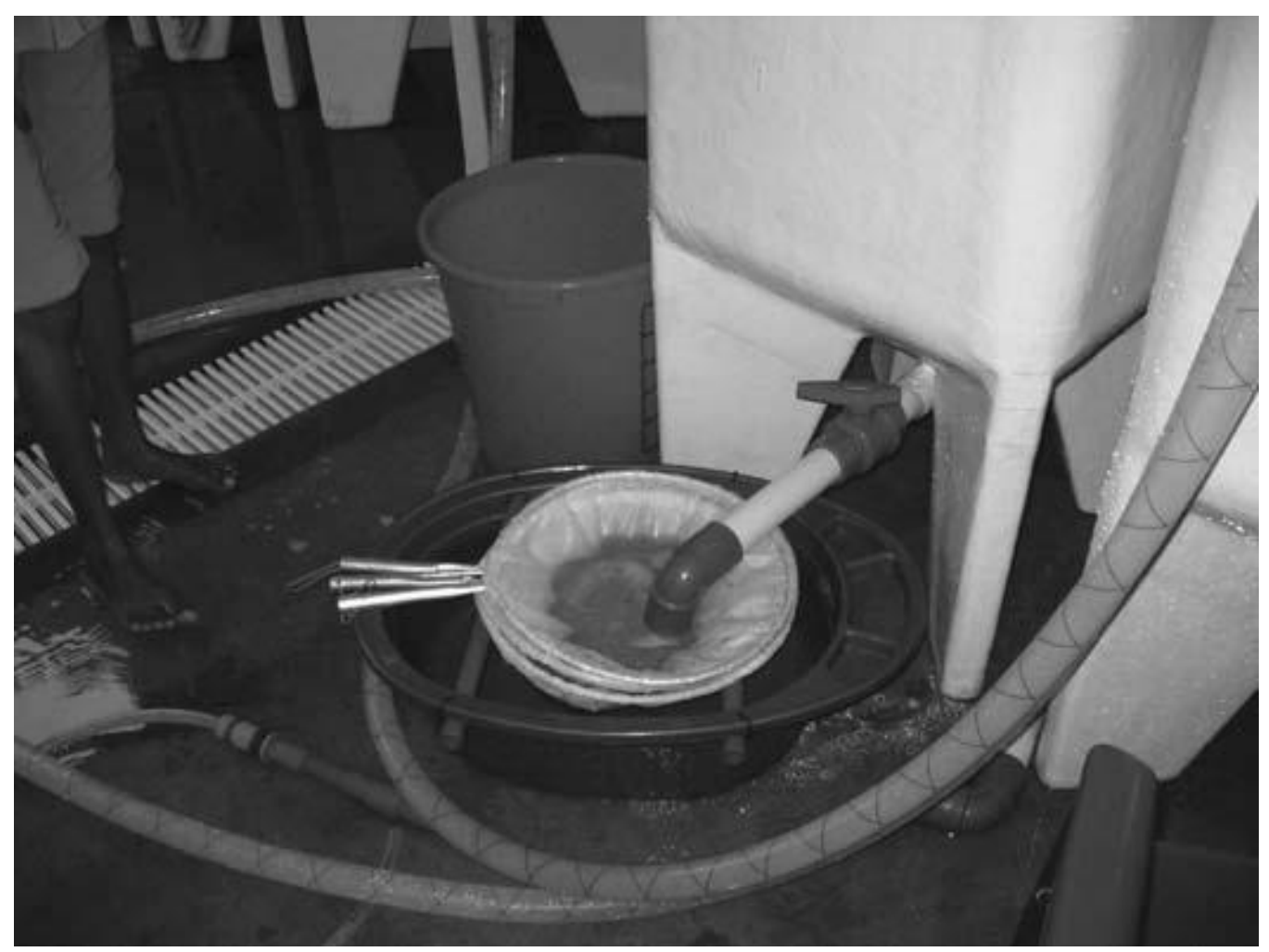

Figure 1. Drain-down of egg incubation and larval culture tanks in a pearl oyster hatchery (Southgate and Lucas 2008).

\section{Nursery culture}

In larval culture, it is important to exchange water periodically and maintain a water temperature range of $27^{\circ}-30^{\circ} \mathrm{C}$ (Rose 1990). In this stage, the first food is introduced and micro algae such as Isochrysis galbana and
Chaetoceros simplex are a good food source (Rose and Baker 1994). After 22 days, larvae are collected with a $140 \mu \mathrm{m}$ mesh sieve (with $198 \mu \mathrm{m}$ diagonal pore size) can be transferred to the tanks which have proper settlement substrate (Rose 1990). Then, from settlement tanks, 
P.maxima spat which have shell height more than $6 \mathrm{~mm}$ are ready to be transferred into the ocean (Dybdahl et al. 1990). Spat are placed in fine mesh to protect them from predators and replace the bigger mesh when they are getting bigger (Southgate and Beer 1997).

\section{Culture systems}

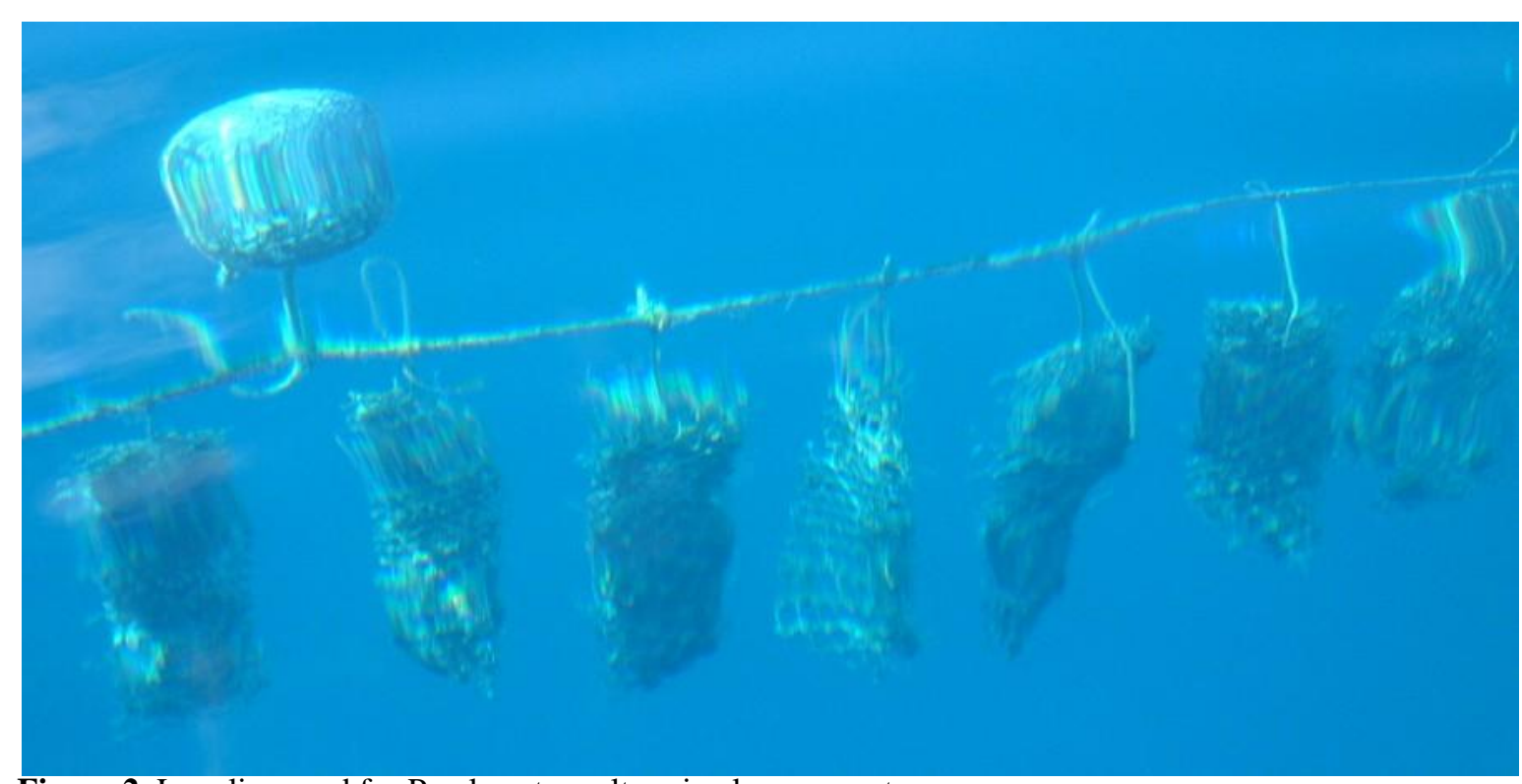

The methods commonly used to growout P.maxima are longline and rafts. Longline are horizontal ropes which are supported by floats and anchored at the final part of ropes to maintain position (Figure 2) (Angell 1986). The length of the ropes depends on the number of P.maxima which are cultured. In Australia, longline can reach up to100 $\mathrm{m}$ long and be deployed side by side $25 \mathrm{~m}$ apart from each other (Wells and Jernakoff2006).

Figure 2. Longline used for Pearl oyster culture in clear sea water

In the raft culture system, raft frames are made from timber, plastic pipe or bamboo and attached by floats like plastic containers, drums or barrels to provide buoyancy (figure 3) (Quayle and Newkirk 1989). To maintain their position, rafts are anchored or have fixed structure like jetties (Angell 1986). Ropes with many individuals of P.maxima are attached hang down on ropes in longline or raft culture system. The advantage of rafts culture compared to longline is 


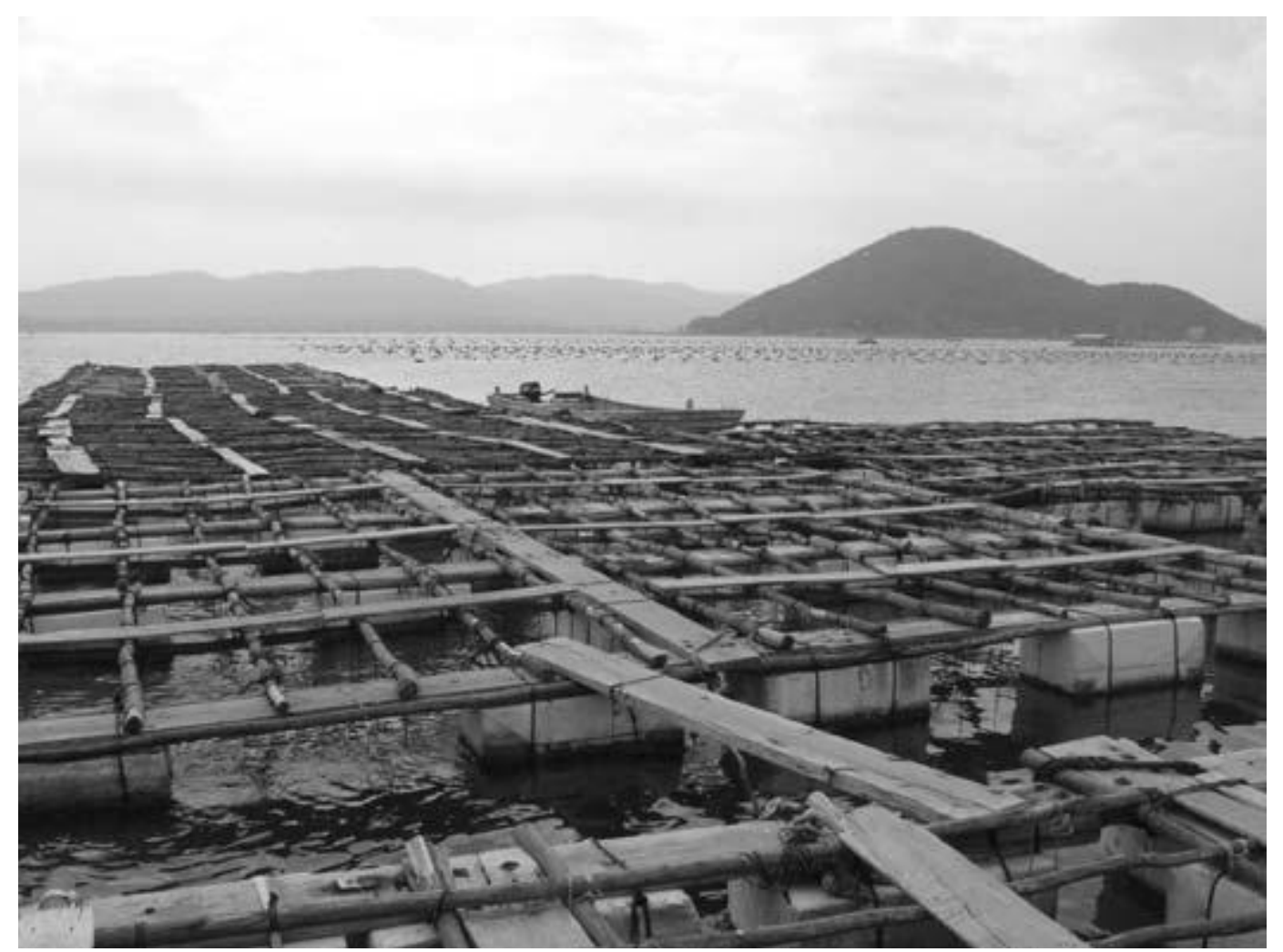

Figure 3. Raft used for pearl culture in Li'an Bay, Hainan Island, China (Southgate and Lucas 2008)

\section{Pearl production}

In pearl production, P.maxima must not undergo gametogenic activity and reduce their metabolic rate by anesthetic agents to prepare for surgery technique of inserting nucleus or mantle section from other oyster into the mantle of P.maxima (Mamangkey et al. 2009). Anesthetic agents also have function to reduce P.maxima stress during operation to maximize success rate in pearl production. After that, they are returned to the farm and after around 2 years they can be harvested (Southgate and Lucas 2008).

\section{Different management practice with Pinctada fucata}

Pearl oyster culture of P.maxima has some different practices from Pinctada fucata. Pinctada fucata are distributed throughout the equatorial zone and the shell size are smaller than P.maxima (Higo et al. 1999). In hatchery production, they are generally placed into the tanks with seawater temperature around $25-28^{\circ} \mathrm{C}$ to induce spawning which $5^{\circ} \mathrm{C}$ lower than
P.maxima (Chellam et al. 1991). Moreover, temperature and salinity of seawater for egg incubation and early nursery culture (period between settlement and transfer spat to field) in $P$. fucata are lower than in P.maxima (Tomaru et al. 2002, Southgate and Lucas 2008). In addition, to minimize mortality, spat size of $P$. fucata should reach at least 3mm (Chellam et al. 1991) and P.maxima around $6 \mathrm{~mm}$ before they are transferred to the wild (Dybdahl et al. 1990).

In Australia, after seeding process which inserts the nucleus into host oyster gonad, P.maxima are put back in the ocean for 7-8 days to facilitate recovery (Wells and Jernakoff 2006), while, in Japan, seeded $P$. fucata are held in deep and calm water for 2-3 weeks (Chellam et al. 1991). After being placed into the ocean, pearls from P.maxima can be harvested after 18 months to 3 years and at least 1 year for $P$. fucata (Gervis and Sims 1992).

\section{Different management practice depend on culture locations}

Besides the differences in management practices with other species, there are also 
different ways to culture P.maxima which vary among different countries. In developed countries such as Japan and Australia, they use fluoroscopy or X-ray to check the position of nucleus or the success of seeding and use high-pressure water pump to clean P.maxima shells. Whereas, in Indonesia and China they place mesh around the pearl oyster following the nucleation procedure to determine the success of seeding and use brushes or knives to clean the pearl oyster because labor cost is low (Southgate and Lucas 2008).

\section{Constraints in Pearl oyster culture}

Pearl oyster culture of P.maxima has limitation factors to achieve good yields. Disease is one of the factors that can reduce the pearl oyster production (Southgate and Lucas 2008). Virus, bacteria, protozoa, metazoan organisms, phytoplankton bloom or combination of them can cause disease in P.maxima. For example, in October 2006, Western Australia, mass mortalities of P.maxima occurred owing to viral infection and disrupted the pearl oyster industry (Southgate and Lucas 2008). Furthermore, blooming of cyanobacterium has also being reported as a major cause of P.maxima death in Australia (Negri et al. 2004). Pinctada maxima that got diseased could be identified by their clinical signs such as reduced growth, mantle retraction, deaths, empty and gaping shells (Southgate and Lucas 2008).

The second common limitation factor for pearl oyster production is predation. There are several predators for pearl oyster that have been reported such as gastropods, turbellarians, crustaceans, octopus, echinoderms fishes and rays (Southgate and Lucas 2008). For instance, in Okinawa-Japan, gastropods have been reported as a serious problem in P.maxima cultures by penetrating their proboscis into P.maxima body. Other pearl oyster predators kill P.maxima by crushing or smashing their shells (crabs or stomatopods, respectively) and from toxins (turbellarians) (Pit and Southgate 2003). Pearl oysters predation will decrease with the raising of oyster size (Southgate and Lucas 2008).

Another management constraint on Pearl oyster culture is biofouling. Fouling organisms (plants or animals) that attach to the shell or mesh and it has impact to pearl and oyster quality or productivity (Pit and Southgate 2003). Physical damage will occurs if fouling organisms such as fungi or porifera bore the P.maxima shells, resulting in nacre or pearl production and even death. Barnacle also disrupts mechanical function such as open and closes the valve of P.maxima by settling on their lip or hinge. Other fouling organism also give negative impact by being a competitor for food resource intake (phytoplankton) (Southgate and Lucas 2008).

\section{Strategies to mitigate pearl oyster culture constraints}

Because the constraints explained above can reduce the product value and productivity, good management strategies are necessary and important to mitigate them. Besides to control or give the best condition such as water quality, $\mathrm{pH}$, salinity, temperature, etc for P.maxima to grow optimum (Southgate and Lucas 2008); there are several approaches to solve management obstacles on P.maxima culture. To inhibit fouling and disease (invasion of other organism), some activity such as cleaning pearl oyster shell periodically and coatings (use chemical treatment) which not danger to environment such as biocidal ingredients are important (Pit and Southgate 2003). Moreover, to avoid predation, some techniques such as to use appropriate size mesh, remove predators from mesh net regularly and suspend the cultured P.maxima in mid-water to avoid benthic predators are proven efficient (Pit and Southgate 2003). Furthermore, a genetic improvement approach may be used to create disease resistant or to improve pearl quality traits such as heavier and gold color in pearl (Southgate and Lucas 2008).

\section{CONCLUSION}

At the end, to achieve good yield and supply market around the world for pearl is necessary. The first step may obtain pearl oyster culture stock from hatchery production rather than from the wild because it gives supply for year around (not depend on environmental conditions) and prevent overexploitation. Furthermore, the larvae can be transfer to nursery culture before placed in open sea water by raft or longline culture system method. As the culture condition in open environment is different compared to in laboratory, some strategies must be applied to mitigate pearl oyster culture constraints (disease, predation, biofouling) by good management culture practice. For instance, it can be achieved by maintaining water quality $(\mathrm{pH}$, temperature, salinity) and providing the best culture condition for Pearl oyster such as remove predators from 
mesh net regularly and suspend the cultured Pearl oyster in mid-water to avoid benthic predators. Moreover, preventing the fouling material or organism to attach in Pearl oyster shell by cleaning or coating the shell is also effective. Genetic approach that can create faster growing Pearl oysters, resistance to diseases and production of higher quality pearls is also good management culture practice. Therefore, any research that support pearl oyster production is needed for better prospect of P.maxima culture.

\section{REFERENCE}

Alagarswami, K., S. Dharmaraj, T. S. Velayudhan, A. Chellam, and A. C. C. Victor. 1983. On the controlled spawning of the Indian pearl oyster Pinctada fucata (Gould). Symposium on coastal aquaculture. Part 2: Molluscan culture. Symp. Ser. Mar. Biol. Assoc. India 6:590-597.

Angell, C. L. 1986. The biology and culture of tropical oysters. ICLARM, Manila, Philippines.

Borowitzka, M. 1997. Microalgae for aquaculture: Opportunities and constraints. Journal of Applied Phycology 9:393-401.

Chellam, A., A. C. C. Victor, S. Dharmaraj, T. S. Velayudhan, and T. S. Satyanaryana. 1991. Pearl oyster farming and pearl culture. Training manual 8. Central marine fisheries research institute, Tuticorin.

Dybdahl, R., S. Harders, and C. Nicholson. 1990. Developing on-growing techniques and disease prevention husbandry of pearl oysters in Western Australia (FIRTA Project 87/81) and on-growing mariculture techniques for the pearl oyster Pinctada maxima spat in Western Australia. Fisheries Department of Western Australia.

Friedman, K. J., J. D. Bell, and G. Tiroba. 1998. Availability of wild spat of the blacklip pearl oyster, Pinctada margaritifera, from 'open' reef systems in Solomon Islands. Aquaculture 167:283-299.
Gervis, M. H. and N. A. Sims. 1992. The biology and culture of pearl oyster (Bivalve: Pteriidae). Manila (Philippines).

Higo, S., P. Callomon, and Y. Goto. 1999. Cataloque and bibliography of the marine shell-bearing mollusca of Japan. Elle science publications, Osaka, Japan.

Hwang, J. and T. Okutani. 2003. Taxonomy and distribution of the genera Pteria and Pinctada (Bivalvia: Pteriidae) in Taiwan. J. Fish. Soc Taiwan 30:199-216.

Mamangkey, N. G. F., H. Acosta-Salmon, and P. C. Southgate. 2009. Use of anaesthetics with the silver-lip pearl oyster, Pinctada maxima (Jameson). Aquaculture 288:280-284.

Negri, A. P., O. Bunter, B. Jones, and L. Llewellyn. 2004. Effect of the bloomforming alga Trichodesmium erythraeum on the pearl oyster Pinctada maxima. Aquaculture 232:91-102.

Pit, J. and P. Southgate. 2003. Fouling and predation; how do they affect growth and survival of the blacklip pearl oyster, Pinctada margaritifera, during nursery culture? Aquaculture International 11:545-555.

Quayle, D. B. and G. F. Newkirk. 1989. Farming bivalve molluscs: method for study and development World aquaculture society, Baton Rouge:292.

Rose, R. A. 1990. A manual for the artificial propagation of the silverlip or goldlip pearl oyster, Pinctada maxima (Jameson) from Western Australia. Fisheries Department, Perth.

Rose, R. A. and S. B. Baker. 1994. Larval and spat culture of the Western Australia silver or goldlip pearl oyster, Pinctada maxima Jameson (Mollusca): Pteriidae. Aquaculture 126:35-50.

Ruiz-Rubio, H., H. Acosta-Salmón, A. Olivera, P. C. Southgate, and C. Rangel-Dávalos. 2006. The influence of culture method and culture period on quality of half- 
Jurnal Saintek Perikanan Vol. 6, No. 2, 2011, 84 - 90

pearls (mabé') from the winged pearl oyster Pteria sterna, Gould, 1851. Aquaculture 254:269-274.

Southgate, P. C. and A. C. Beer. 1997. Hatchery and early nursery culture of the blacklip pearl oyster Pinctada margaritifera (L.). J. Shellfish. Res 16:561-568.

Southgate, P. C. and J. S. Lucas, editors. 2008. The pearl oyster. Elsevier, Amsterdam.

Sue. 2003. Read about diving in Fakarava. http://hackingfamily.com/landfalls/Frenc h_Polynesia/fakarava.htm

Taylor, J. J., P. C. Southgate, and R. A. Rose. 1997. Fouling animals and their effect on the growth of silver-lip pearl oyster, Pinctada maxima (Jameson) in suspended culture. Aquaculture 153:3140.

Tomaru, Y., Y. Kumatabara, Z. Kawabata, and S. Nakano. 2002. Effect of water temperature and chlorophyll abundance on shell growth of the Japanese pearl oyster, Pinctada fucata martensii, in suspended culture at different depths and sites. Aquaculture Research 33:109-116.

Vakily, J. M. 1989. The biology and culture of mussels of the genus Perna. ICLARM Stu. Rev. 1763.

Wells, F. E. and P. Jernakoff. 2006. An assessment of the environmental impact of wild harvest pearl aquaculture (Pinctada maxima) in Western Australia. Shellfish Res 25:141-147. 